31. Teplaya, G. A. (2013). Tyazhelye metally kak faktor zagryazneniya okruzhayushchei sredy (obzor literatury). Astrakhanskii vestnik ekologicheskogo obrazovaniya, 1(23), 182-192.

32. Ushakov, A. A., Turbinskii, V. V., Pashchenko, I. G., \& Katunina, A. S. (2015). Gigienicheskaya otsenka sotsial'-nykh, sanitarno-gigienicheskikh faktorov okruzhayushchei sredy na territorii Altaiskogo kraya. Analiz ris-ka zdorov'yu, (4), 50-61.

33. Kharlamova, E. N., \& Val'tseva, E. A. (2014). Otsenka vliyaniya faktorov sredy na zabolevaemost' organov dy-khaniya i serdechnososudistoi sistemy sredi podrostkov g. Samary. Gigiena i sanitariya, (6), 87-91.

34. Choinzonov, E. L., Mukhamedov, M. R., \& Balatskaya, L. N. (2006). Rak gortani: sovremennye aspekty lecheniya i reabilitatsii. Tomsk.

35. Chubirko M. I., Pichuzhkina N. M. Chubirko, M. I., \& Pichuzhkina, N. M. (2008). Gigienicheskaya diagnostika vliyaniya zagryazneniya atmosfernogo vozdukha na zdorov'e naseleniya. Zdorov'e naseleniya i sreda obitaniya, (1). 19-20. (In Russian).

УДК 574.24:631.42

https://doi.org/10.36906/2311-4444/20-1/18

М. Ю. Гарицкая, Т. Н. Холодилина, М. С. Баранова

ЭКОЛОГИЧЕСКАЯ ХАРАКТЕРИСТИКА КАЧЕСТВА
ПОЧВ ПРИДОРОЖНЫХ ТЕРРИТОРИЙ,
ИСПОЛЬЗУЕМЫХ ДЛЯ ВЫРАЩИВАНИЯ
СЕЛЬСКОХОЗЯЙСТВЕННЫХ КУЛЬТУР

M. Y. Garitskaya, T. N. Kholodilina, M. S. Baranova

\title{
ECOLOGICAL CHARACTERISTICS OF SOIL QUALITY OF ROADSIDE AREAS USED FOR GROWING CROPS
}

\begin{abstract}
Аннотация. В статье приводятся данные по исследованию содержания тяжелых металлов в почвах придорожных территорий трасс, соединяющих такие населенные пункты как Оренбург-Орск и Саракташ-Кувандык (земли транспорта), Оренбургской области, используемые для выращивания сельскохозяйственных культур. Было изучено два сельскохозяйственных поля, пшеничное и ячменное, расположенные между автомобильными трассами и лесозащитными полосами. Цель работы - исследовать содержание в почвах валовых и подвижных форм тяжелых металлов и дать оценку качества почв по степени экологического неблагополучия, а также возможности использования их под сельскохозяйственные культуры. Для оценки экологического состояния использовали суммарный показатель химического загрязнения и экотоксикологический показатель качества почв. В отобранных образцах почв определяли содержание следующих тяжелых металлов: кадмий, цинк, свинец, марганец, железо, медь, хром, кобальт, никель. Установлено, что максимальное процентное содержание подвижных форм от валового количества в почвах, отобранных вдоль трассы Саракташ-Кувандык, наблюдается по кадмию (9-17\%), а в почвенных образцах, отобранных в придорожной зоне трассы Оренбург-Орск - по свинцу (5,7-11,5\%). Согласно показателю химического загрязнения (ПХЗ) почв и существующим критериям, всю исследуемую придорожную территорию можно отнести к зоне с критической экологической ситуацией $(16<$ ПХ3 $<32)$, а территорию на расстоянии 6 метров от дорожного полотна трассы Оренбург-Орск - к зоне с чрезвычайной экологической ситуацией $(32<\Pi Х 3<128)$. Анализ полученных данных экотоксикологического показателя, дифференцированно для веществ различного класса опасности, показал, что по металлам I класса опасности на всей исследуемой нами территории складывается чрезвычайная экологическая ситуация, за исключением территории на расстоянии 6 и 16 метров от дорожного полотна трассы Оренбург-Орск, где
\end{abstract}

Abstract. This paper presents data on the content of heavy metals in the road-side soils (transport lands) along the Orenburg-Orsk motorway and the Saraktash-Kuvandyk motorway in Orenburg Region, Russia. The objects of the study were two agricultural fields (wheat and barley) located between the motorway and the forest shelterbelt. The purpose of the study was to find the total content and the active form of heavy metals in the studied soils, to assess their quality by the degree of ecological adversity, and to determine the possibility of using them for cultivating crops. The comprehensive chemical pollution indicator (CCPI) and the ecotoxicological soil quality indicator (ESQI) were used to assess the ecological condition of the studied fields. The soil samples were tested to find the content of cadmium, zinc, lead, manganese, iron, copper, chromium, cobalt, and nickel. Cadmium had the highest active form percentage (9-17\%) in the total heavy metal content in soils, sampled along the Saraktash-Kuvandyk motorway, while lead content was the highest $(5.7-11.5 \%)$ in samples collected along the Orenburg-Orsk motorway. According to the CCPI and other established criteria, the entire territory along the motorways is in the critical environmental condition $(16<\mathrm{CCPI}<32)$, and the territory six meters away from the Orenburg-Orsk motorway is in the condition of environmental emergency $(32<$ CCPI < 128). The ESQI data was analyzed differentially for substances of various hazard classes. As for hazard class I metals, the environmental emergency has already developed throughout the territory under study, except for the areas located six and sixteen meters from the 
складывается зона экологического бедствия. Таким образом, анализ экологического состояния исследуемых нами придорожных территорий показал, что по валовой форме содержания наиболее токсичных металлов, относящихся к I классу опасности, их можно отнести к зонам с чрезвычайной экологической ситуацией и ситуацией экологического бедствия, и данные территории не должны использоваться для выращивания сельскохозяйственных культур, идущих на изготовление продуктов питания и корм скоту.

Ключевые слова: придорожная территория; почва; тяжелые металлы; показатель химического загрязнения; экологическая ситуация.
Orenburg-Orsk motorway that are in the state of environmental disaster. Therefore, the analysis of the ecological state of the studied road-side areas showed that, by the total content of toxic hazard class I metals, they can be categorized as environmental emergency and environmental disaster zones, and crops, used for producing foodstuff and livestock feed, must not be cultivated in these fields.

Key words: roadside territory; soil; heavy metal; chemical pollution indicator; environmental situation.

Сведения об авторах: Гарицкая Марина Юрьевна, SPIN-код: 1889-5465, канд. биол. наук, Оренбургский государственный университет, г. Оренбург, Россия, m.garitskaya@yandex.ru, Холодилина Татьяна Николаевна, SPIN-код: 2977-6059, канд. с.-х. наук, Оренбургский государственный университет, г. Оренбург, Россия, xolodilina@rambler.ru, Баранова Маргарита, Оренбургский государственный университет, г. Оренбург, Россия.

Information about the authors: Garitskaya Marina Yurievna, SPIN-code: 1889-5465, PhD, Orenburg State University, Orenburg, Russia, m.garitskaya@yandex.ru; Kholodilina Tatiana Nikolaevna, SPIN-code: 2977-6059, Ph.D., Orenburg State University, Orenburg, Russia, xolodilina@rambler.ru; Baranova Margarita, Orenburg State University, Orenburg, Russia.

\section{Введение}

Общая площадь территории Оренбургской области составляет 123,7 тыс. км², из которых земли сельскохозяйственных угодий составляют 10 576,6 тыс. га. Это приблизительно 88\% территории, в структуру которой входит пашня $(\approx 56,5 \%)$, многолетние насаждения $(\approx 0,2 \%)$, сенокосы $(\approx 6,5 \%)$, пастбища $(\approx 36,8 \%)$ [6].

Высокоплодородные почвы, распространенные в регионе, определяют основное направление сельского хозяйства - земледелие. Причем 70\% посевных площадей занято под зерновые культуры, главная из которых - пшеница, как озимая, так и яровая, в том числе твердых сортов, которая дает высококачественное зерно для выработки муки высшего сорта. Кроме этого выращивают рожь (озимую), ячмень (озимый, яровой), овес, гречиху, просо, кукурузу (зерно, корм), нут, подсолнечник (зерно, силос), сахарную свеклу, рапс (яровой), картофель, тыквы, арбузы, дыни, ягоды, однолетние и многолетние травы.

Земли сельскохозяйственного назначения имеют особый правовой режим и подлежат особой охране. Они неоднородны по своему составу, и в соответствии со статьей 77 ЗК РФ подразделяются на сельскохозяйственные угодья (к ним относятся сельскохозяйственные угодья и особо ценные продуктивные сельскохозяйственные угодья) и несельскохозяйственные угодья - это земли, занятые внутрихозяйственными дорогами, коммуникациями, древесно-кустарниковой растительностью, предназначенной для обеспечения защиты земель от воздействия негативных (вредных) природных, антропогенных и техногенных явлений, замкнутыми водоёмами, а также зданиями, строениями, сооружениями, используемыми для производства, хранения и первичной переработки сельскохозяйственной продукции [16].

Проблеме загрязнения окружающей среды выбросами от автомобильного транспорта и транспортно-дорожного комплекса в целом посвящено достаточно большое количество публикаций. Особое внимание уделяется урбанизированным территориям, где данный источник загрязнения является, как правило, приоритетным и может оказывать значительное влияние на здоровье населения [9; 14; 24$]$.

Тенденция к увеличению удельного веса всех типов автомобильного транспорта на уличнодорожной сети приводит к нарастанию экологической нагрузки на придорожную территорию. Вопрос загрязнения почв прилегающих к дороге территорий тяжелыми металлами, нефтепродуктами, компонентами отработанных газов двигателей является предметом активного изучения $[8 ; 15 ; 19 ; 23 ; 26]$. Рассеивание выбросов от автотранспорта в зависимости от дисперсности частиц может происходить на расстоянии от десяти, до сотен метров в случае отсутствия защитных лесополос [10; 11$]$.

Увеличение концентраций тяжелых металлов в придорожных почвах может приводить к долгосрочным экологическим последствиям. Анализ результатов биомоноторинга на различных придорожных территориях показывает накопление тяжелых металлов как во внутренних органах живых организмов [24], так и в тканях растений [1; 18], имеются данные о повреждении их ДНК [22].

В Оренбургской области в качестве земель для выращивания той или иной сельскохозяйственной продукции нередко используются придорожные территории вдоль крупных магистралей, находящиеся в зоне их техногенного воздействия, т. е. происходит использование земель транспорта не по их 
целевому назначению. Зачастую это полоски земли, расположенные между автодорогой и лесополосой, где аккумулируется основная масса автотранспортных выбросов. Актуальным является мониторинг придорожного загрязнения, выявление приоритетных поллютантов, которые могут быть опасными для здоровья человека в результате миграции по пищевым путям [2; 21].

Такие исследования позволят предотвратить возможность засева загрязненных почв сельскохозяйственными культурами [3; 20].

Целью работы являлось определение содержания валовых и особо опасных подвижных форм тяжелых металлов в почвах придорожных территорий, используемых для выращивания различных сельскохозяйственных культур.

\section{Общая характеристика объектов исследования}

Наибольшую опасность представляют тяжелые металлы автотранспортного происхождения, которые попадают на поверхность почвы придорожной территории в результате сухого осаждения и вымывания осадками. Большая часть из них включается в процессы почвообразования и поглощается растениями, в результате чего вдоль автомобильных дорог формируются геохимические аномалии тяжелых металлов [7; 12].

Первым объектом было выбрано ячменное поле, располагающееся вдоль трассы, соединяющей Саракташ и Кувандык, в непосредственной близости от села Зиянчурино. Пробы почв отбирались на расстоянии 3 метров от дорожного полотна - это кромка засеянного поля, и далее на расстоянии 20 и 40 метров от края дороги вдоль трассы.

Вторым объектом исследования было пшеничное поле, расположенное вдоль трассы ОренбургОрск, в трех километрах от села Лылово. Почвенные образцы отбирались с шагом в 10 метров на расстоянии 6, 16, 26 и 36 метров от дорожного полотна. Поля с одной стороны ограничены дорожным полотном, а с другой лесополосой.

\section{Методы исследования}

Пробы отбирали согласно ГОСТ 17.4.4.02-84 «Охрана природы (ССОП). Почвы. Методы отбора и подготовки проб для химического, бактериологического, гельминтологического анализа».

Исследования по определению тяжелых металлов в почве проводили в испытательном центре ФГБНУ ФНЦ «Биологических систем и агротехнологий РАН». Содержание тяжелых металлов определяли по ПНД Ф 16.1:2:2.2:2.3.78-2013 «Методика измерений массовой доли подвижных форм металлов: меди, цинка, свинца, кадмия, марганца, никеля, кобальта, хрома в пробах почв, грунтов, донных отложений, осадков сточных вод методом пламенной атомно-адсорбционной спектрометрии»; ПНД Ф 16.1:2:2.2:2.3.36-2002 «Методика измерений валового содержания меди, цинка, свинца, кадмия, марганца, никеля в пробах почв, грунтов, донных отложений, осадков сточных вод методом пламенной атомно-адсорбционной спектрометрии».

Для оценки экологического состояния почв использовали суммарный показатель химического загрязнения (Zc) [4]:

$$
Z c=\sum_{i=1}^{n} K c_{i}
$$

где $K_{C i}$ - коэффициент концентрации $i$-го загрязняющего компонента, представляющий собой частное от деления массовой доли $i$-го вещества в загрязненной и «фоновой» почве для тяжелых металлов.

Расчет коэффициента концентрации проводили относительно фоновых значений содержания тяжелых металлов в почвах, представленных в таблице 3.

Более значимым является экотоксикологический показатель качества почв, представляющий собой отношение концентрации полютанта к его предельно допустимому значению: Э концентрация і-примеси в почве, мг/кг, ПДК - предельно допустимая концентрация і-примеси в почве, мг/кг.

Так как почвы загрязняются веществами, различными по своей токсичности, то для их экотоксикологической характеристики использовали кратность превышения ПДК конкретного загрязняющего вещества, дифференцированно для веществ различных классов опасности (Чекмарева и др. 2015).

При этом оценка экологического состояния почв осуществлялась по величинам критериев, представленных в таблице 1 [13].

\section{Критерии оценки степени химического загрязнения почвенного покрова}

Таблица 1

\begin{tabular}{|c|c|c|c|}
\hline Показатели & $\begin{array}{c}\text { Экологическое } \\
\text { бедствие }\end{array}$ & $\begin{array}{c}\text { Чрезвычайная эколо- } \\
\text { гическая ситуация }\end{array}$ & $\begin{array}{c}\text { Относительно удовлетво- } \\
\text { рительная ситуация }\end{array}$ \\
\hline
\end{tabular}




\begin{tabular}{|l|c|c|c|}
\hline $\begin{array}{l}\text { Суммарный показатель химического } \\
\text { загрязнения почв, Zc }\end{array}$ & $>128$ & $32-128$ & $<16$ \\
\hline Превышение ПДК хим. веществ в & & & \\
почве: & $>3$ & $2-3$ & $<1$ \\
I класса опасности, Э $Э_{1}$ & $5-10$ & $<1$ \\
II класса опасности, Э & $>10$ & $10-20$ & $<1$ \\
III класса опасности, Э & $>20$ & & \\
\hline
\end{tabular}

Результаты исследований

В отобранных образцах почв определяли содержание следующих тяжелых металлов: кадмий, цинк, свинец, марганец, железо, медь, хром, кобальт, никель. Результаты, полученные в ходе химического анализа, представлены в таблицах 2 и 3.

Исходя из представленных данных, можно сделать вывод, что в основной массе проб концентрации металлов уменьшаются при увеличении расстояния от дорожного полотна в среднем в 1,1-2 раза, что свидетельствует о влиянии автодорожного комплекса на их содержание в почве.

Максимальное процентное содержание подвижных форм от валового количества в почвах, отобранных вдоль трассы Саракташ-Кувандык, наблюдается по кадмию и составляет 9-17\%. По марганцу данный показатель изменяется в пределах 8,9-10 \%, а по свинцу 2,9-5\%.

Таблица 2

Содержание тяжелых металлов в почве придорожной территории трассы Саракташ-Кувандык

\begin{tabular}{|c|c|c|c|c|c|c|c|c|c|}
\hline \multirow{3}{*}{ Расстояние, м } & \multicolumn{9}{|c|}{ Концентрация, мг/кг } \\
\hline & $\mathrm{Cd}$ & $\mathrm{Zn}$ & $\mathrm{Pb}$ & $\mathrm{Mn}$ & $\mathrm{Fe}$ & $\mathrm{Cu}$ & $\mathrm{Cr}$ & $\mathrm{Co}$ & $\mathrm{Ni}$ \\
\hline & \multicolumn{7}{|c|}{ Подвижная форма } & & \\
\hline 3 & 0,21 & 1,20 & 1,50 & 58,7 & 1,20 & 0,60 & 0.23 & 0,27 & 1.10 \\
\hline 20 & 0,27 & 0,60 & 0,70 & 69,7 & 3,70 & 0,67 & 0,24 & 0,37 & 0,80 \\
\hline 40 & 0,31 & 0,80 & 0,71 & 46,2 & 0,85 & 0,31 & 0,16 & 0,29 & 1.10 \\
\hline \multicolumn{10}{|c|}{ Валовая форма } \\
\hline 3 & 2,30 & 72,0 & 30,0 & 660 & 35500 & 33,0 & 69,0 & 20,0 & 90,0 \\
\hline 20 & 2,0 & 59,0 & 24,0 & 690 & 30000 & 34,0 & 67,0 & 19,0 & 92,0 \\
\hline 40 & 1,80 & 54,0 & 23,0 & 519 & 26500 & 29,0 & 54,0 & 15,0 & 70,0 \\
\hline
\end{tabular}

Таблица 3

Содержание тяжелых металлов в почве придорожной территории трассы Оренбург-Орск

\begin{tabular}{|c|c|c|c|c|c|c|c|c|c|}
\hline \multirow{3}{*}{ Расстояние, м } & \multicolumn{9}{|c|}{ Концентрация, мг/кг } \\
\hline & $\mathrm{Cd}$ & $\mathrm{Zn}$ & $\mathrm{Pb}$ & $\mathrm{Mn}$ & $\mathrm{Fe}$ & $\mathrm{Cu}$ & $\mathrm{Cr}$ & $\mathrm{Co}$ & $\mathrm{Ni}$ \\
\hline & \multicolumn{7}{|c|}{ Подвижная форма } & & \\
\hline 6 & 0,36 & 3,20 & 1,90 & 54,4 & 2,10 & 0,65 & 0.54 & 0,15 & 0,87 \\
\hline 16 & 0,12 & 2,70 & 2,20 & 49,2 & 2,30 & 0,61 & 0,32 & 0,28 & 0,74 \\
\hline 26 & 0,13 & 1,70 & 2,40 & 47,3 & 2,00 & 0,49 & 0,27 & 0,23 & 0.62 \\
\hline 36 & 0,14 & 1,70 & 1,20 & 50,7 & 2,60 & 0,32 & 0,21 & 0,42 & 0,75 \\
\hline \multicolumn{10}{|c|}{ Валовая форма } \\
\hline 6 & 3,30 & 108 & 33,0 & 690 & 36500 & 113 & 60,0 & 19,0 & 58,0 \\
\hline 16 & 2,90 & 85,0 & 25,0 & 625 & 33700 & 110 & 56,0 & 20,0 & 42,0 \\
\hline 26 & 2,10 & 73,0 & 25,0 & 573 & 32600 & 66,0 & 59,0 & 20,0 & 47,0 \\
\hline 36 & 2,50 & 74,0 & 29,0 & 555 & 27100 & 76,0 & 52,0 & 16,0 & 44,0 \\
\hline фоH & 0,25 & 39,9 & 10,4 & 551,2 & 22607 & 18,5 & 44,4 & 10,3 & 50,6 \\
\hline
\end{tabular}

В почвенных образцах, отобранных в придорожной зоне трассы Оренбург-Орск, наблюдается обратная зависимость. Наибольший процентный вклад в загрязнение почв подвижной формой относительно валового содержания вносит свинец $(5,7-11,5 \%)$, далее идут марганец $(7,9-9 \%)$ и кадмий (4$10 \%)$.

Проведенный нами расчет коэффициентов концентраций валового содержания тяжелых металлов в почвах показал, что наибольшие значения $\mathrm{K}_{\mathrm{c}}$, равные 8,4-13,2, наблюдаются по кадмию во всех точках отбора проб. В почвах, отобранных в придорожной территории трассы Саракташ-Кувандык, среди металлов I класса опасности наибольшее превышение фона также наблюдается по свинцу (2,92,2 раза). 
В почвенных пробах, отобранных вдоль трассы Оренбург-Орск, существенное превышение фона по меди и свинцу составляет $3,57-6,1$ и 2,4-3,18 соответственно (табл. 4).

Таблица 4

Коэффициенты концентраций тяжелых металлов в почве

\begin{tabular}{|c|c|c|c|c|c|c|c|c|c|c|}
\hline \multirow{3}{*}{$\begin{array}{c}\text { Расстояние, } \\
\text { м }\end{array}$} & \multicolumn{10}{|c|}{ Коэффициент концентрации } \\
\hline & $\mathrm{K}_{\mathrm{Cd}}$ & $\mathrm{K}_{\mathrm{Zn}}$ & $\mathrm{K}_{\mathrm{Pb}}$ & $\mathrm{K}_{\mathrm{Mn}}$ & $\mathrm{K}_{\mathrm{Fe}}$ & $\mathrm{K}_{\mathrm{Cu}}$ & $\mathrm{K}_{\mathrm{Cr}}$ & $\mathrm{K}_{\mathrm{Co}}$ & $\mathrm{K}_{\mathrm{Ni}}$ & $\mathrm{Z}_{\mathrm{c}}$ \\
\hline & \multicolumn{10}{|c|}{ Саракташ-Кувандык } \\
\hline 3 & 9,20 & 1,80 & 2,90 & 1,20 & 1,57 & 1,78 & 1,55 & 1,93 & 1,77 & 23,7 \\
\hline 20 & 8,00 & 1,48 & 2,36 & 1,25 & 1,33 & 1,84 & 1,51 & 1,83 & 1,82 & 21,4 \\
\hline 40 & 7,20 & 1,35 & 2,21 & 0,94 & 1,17 & 1,57 & 1,22 & 1,45 & 1.38 & 18,5 \\
\hline \multicolumn{11}{|c|}{ Оренбург-Орск } \\
\hline 6 & 13,2 & 2,71 & 3,18 & 1,25 & 1,61 & 6,10 & 1,35 & 1,83 & 1,14 & 32,4 \\
\hline 16 & 11,6 & 2,13 & 2,41 & 1,13 & 1,49 & 5,90 & 1,26 & 1,93 & 0,83 & 28,7 \\
\hline 26 & 8,40 & 1,83 & 2,41 & 1,04 & 1,44 & 3,57 & 1,32 & 1,93 & 0,93 & 22,9 \\
\hline 36 & 10,0 & 1,85 & 2,79 & 1,01 & 1,20 & 4,11 & 1,17 & 1,54 & 0,87 & 24,5 \\
\hline
\end{tabular}

Согласно показателю химического загрязнения (ПХЗ) почв и критериям, приведенным в таблице 1 , всю исследуемую придорожную территорию можно отнести к зоне с критической экологической ситуацией, а территорию на расстоянии 6 метров от дорожного полотна трассы Оренбург-Орск - к зоне с чрезвычайной экологической ситуацией.

При значениях ПХЗ от 16 до 32 почва относится к умеренно опасной категории загрязнения и может использоваться для выращивания сельскохозяйственных культур только при строгом контроле качества продукции растениеводства. А если этот показатель превышает 32, то почва относится к высоко опасной категории загрязнения и не может использоваться для выращивания культур, применяемых для получения продуктов питания или идущих на корм скоту. В нашем случае это пшеничное поле, и по всей видимости конечным продуктом будет являться мука и производимые из нее продукты питания.

Анализ полученных данных экотоксикологического показателя, дифференцированно для веществ различного класса опасности, показал, что если по валовому содержанию металлов II и III классов опасности наблюдается критическая экологическая ситуация, то по металлам I класса опасности чрезвычайная, за исключением территории на расстоянии 6 и 16 метров от дорожного полотна трассы Оренбург-Орск, где складывается зона экологического бедствия (табл. 5, 6).

Таблица 5

Значение экотоксикологического показателя качества почв трассы Саракташ-Кувандык

\begin{tabular}{|c|c|c|c|c|c|c|c|c|c|c|c|c|}
\hline \multirow{3}{*}{ Расстояние, м } & \multicolumn{12}{|c|}{ Значения Эс для тяжелых металлов различных классов опасности } \\
\hline & \multicolumn{4}{|c|}{ I класса опасности } & \multicolumn{5}{|c|}{ II класса опасности } & \multicolumn{3}{|c|}{ III класса опасности } \\
\hline & $\mathrm{Cd}$ & $\mathrm{Zn}$ & $\mathrm{Pb}$ & $Э_{\mathbf{I}}$ & $\mathrm{Cu}$ & $\mathrm{Cr}$ & Co & $\mathrm{Ni}$ & $Э_{\text {II }}$ & $\mathrm{Mn}$ & $\mathrm{Fe}$ & $Э_{\text {III }}$ \\
\hline \multicolumn{13}{|c|}{ Подвижная форма } \\
\hline 3 & 1,05 & 0,05 & 0,25 & 1,35 & 0,2 & 0,04 & 0,05 & 0,27 & $\mathbf{0 , 5 6}$ & 0,42 & 1.57 & 1,99 \\
\hline 20 & 1,35 & 0,03 & 0,12 & 1,50 & 0,22 & 0,04 & 0,07 & 0,20 & $\mathbf{0 , 5 3}$ & 0,50 & 1,33 & 1,83 \\
\hline 40 & 1,55 & 0,03 & 0,12 & 1,70 & 0,10 & 0,03 & 0,06 & 0,27 & 0,46 & 0,33 & 1,17 & 1,50 \\
\hline \multicolumn{13}{|c|}{ Валовая форма } \\
\hline 3 & 1,15 & 0,72 & 1,00 & 2,87 & 0,60 & 0,69 & 1,25 & 1,06 & 3,60 & 0,44 & 1,42 & 1,86 \\
\hline 20 & 1,00 & 0,59 & 0,80 & 2,39 & 0,62 & 0,67 & 1,19 & 1,08 & 3,56 & 0,46 & 1,20 & 1,66 \\
\hline 40 & 0,90 & 0,54 & 0,77 & 2,21 & 0,53 & 0,54 & 0,94 & 0,82 & 2,83 & 0,35 & 1,06 & 1,41 \\
\hline
\end{tabular}

Таблица 6

Значение экотоксикологического показателя качества почв трассы Оренбург-Орск

\begin{tabular}{|c|c|c|c|c|c|c|c|c|c|c|c|c|}
\hline \multirow{3}{*}{ Расстояние, м } & \multicolumn{12}{|c|}{ Значения Э. для тяжелых металлов различных классов опасности } \\
\hline & \multicolumn{4}{|c|}{ I класса опасности } & \multicolumn{5}{|c|}{ II класса опасности } & \multicolumn{3}{|c|}{ III класса опасности } \\
\hline & $\mathrm{Cd}$ & $\mathrm{Zn}$ & $\mathrm{Pb}$ & ЭI & $\mathrm{Cu}$ & $\mathrm{Cr}$ & $\mathrm{Co}$ & $\mathrm{Ni}$ & ЭII & $\mathrm{Mn}$ & $\mathrm{Fe}$ & ЭIII \\
\hline \multicolumn{13}{|c|}{ Подвижная форма } \\
\hline 6 & 1,80 & 0,14 & 0,32 & 2,26 & 0,22 & 0,09 & 0,03 & 0,22 & $\mathbf{0 , 5 6}$ & 0,39 & & 1,99 \\
\hline 16 & 0,60 & 0,12 & 0,37 & 1,09 & 0,20 & 0,05 & 0,06 & 0,18 & 0,49 & 0,35 & & 1,83 \\
\hline 26 & 0,65 & 0,07 & 0,40 & 1,12 & 0,16 & 0,04 & 0,05 & 0,15 & 0,40 & 0,34 & & 1,50 \\
\hline 36 & 0,70 & 0,07 & 0,2 & 0,97 & 0,11 & 0,03 & 0,04 & 0,19 & $\mathbf{0 , 3 7}$ & 0,36 & & \\
\hline
\end{tabular}




\begin{tabular}{|c|c|c|c|c|c|c|c|c|c|c|c|c|}
\hline \multicolumn{10}{|c|}{ Валовая форма } \\
\hline $\mathbf{6}$ & 1,65 & 1,08 & 1,1 & $\mathbf{3 , 8 3}$ & 2,05 & 0,6 & 1,19 & 0,68 & $\mathbf{4 , 5 2}$ & 0,46 & 1,46 & $\mathbf{1 , 9 2}$ \\
\hline $\mathbf{1 6}$ & 1,45 & 0,85 & 0,83 & $\mathbf{3 , 1 3}$ & 2,0 & 0,56 & 1,25 & 0,49 & $\mathbf{4 , 3}$ & 0,42 & 1,35 & $\mathbf{1 , 7 7}$ \\
\hline $\mathbf{2 6}$ & 1,05 & 0,73 & 0,83 & $\mathbf{2 , 6 1}$ & 1,2 & 0,59 & 1,25 & 0,55 & $\mathbf{3 , 5 9}$ & 0,38 & 1,3 & $\mathbf{1 , 6 8}$ \\
\hline $\mathbf{3 6}$ & 1,25 & 0,74 & 0,97 & $\mathbf{2 , 9 6}$ & 1,38 & 0,52 & 1,00 & 0,52 & $\mathbf{3 , 4 2}$ & 0,37 & 1.1 & $\mathbf{1 , 4 7}$ \\
\hline
\end{tabular}

\section{Выводы}

Исходя из полученных данных, наихудшая экологическая ситуация наблюдается по металлам I класса опасности. Лишь в одной из отобранных нами проб почв не наблюдается превышения ПДК по валовому содержанию кадмия. На сегодняшний день загрязнение почв кадмием является одной из опасных экологических проблем, так как растения способны накапливать его выше нормы даже при незначительном загрязнении почв. Исследования показали, что кадмий является приоритетным металлом, как по коэффициенту концентрации, так и по экотоксикологическому показателю качества почв.

В непосредственной близости от дорожного полотна $(3,6$ м) наблюдается также превышение ПДК валовой формы свинца. Из металлов II и III классов опасности значения ПДК валовых форм превышены по кобальту и железу во всех точках отбора проб.

Анализ экологического состояния исследуемых придорожных зон показал, что по валовой форме содержания наиболее токсичных металлов, относящихся к I классу опасности, их можно отнести к зонам с чрезвычайной экологической ситуацией и зонам экологического бедствия.

Согласно данным, приведенным в госдокладе «О состоянии и об охране окружающей среды Оренбургской области в 2017 году», придорожная территория трассы Оренбург-Орск относится к землям транспорта, и в результате мониторинговых исследований снеговой воды там было выявлено, что содержание почти всех тяжелых металлов и микроэлементов значительно превышает ПДК. В смешанных образцах почв превышение ПДК практически отсутствует, что свидетельствует о высокой миграционной способности загрязняющих элементов по профилю почв и аккумуляции растениями. Установлено, что придорожные лесополосы являются частью естественного биогеохимического барьера и значительно снижают концентрацию загрязняющих элементов, препятствуя их распространению [5].

Исходя из этих выводов, в придорожных зонах, ограниченных лесополосами, идет интенсивное загрязнение воздушной среды и почв тяжелыми металлами, но в результате их поглощения растениями почвы самоочищаются. Следовательно, исследуемые нами придорожные территории не должны использоваться для выращивания сельскохозяйственных культур, идущих на изготовление продуктов питания и корм скоту.

\section{ЛИТЕРАТУРА}

1. Богуславская Н. В. Эколого-токсикологическая оценка содержания тяжелых металлов в агроландшафтах Белгородской области [Полевые опыты по содержанию кадмия в почве и его накоплению в растениях яровой пшеницы] // Экологическая безопасность в АПК. Реферативный журнал. 2010. № 1. С. 108-108.

2. Водяницкий Ю. Н. и др. Влияние техногенных и природных факторов на содержание тяжелых металлов в почвах Среднего Предуралья (г. Чусовой и его окрестности) // Почвоведение. 2010. № 9. С. 1089-1099.

3. Гайлитис Д. И., Тулянкина Н. А. Биотестирование почв с целью оценки загрязнения придорожной полосы // Проблемы инновационного биосферно-совместимого социально-экономического развития в строительном, жилищнокоммунальном и дорожном комплексах. 2015. С. 186-189.

4. Гарицкая М. Ю., Чекмарева О. В., Ишанова О. С., Патокина Н. С. Химическое загрязнение почв территории, прилегающей к Сорочинско-Никольскому месторождению // Вестник Оренбургского государственного университета. 2015. № 6(181). С. $85-88$.

5. Госдоклад «О состоянии и об охране окружающей средыв Оренбургской области в 2017 году». https:/gosdokladecology.ru/2017/subjects/pfo/orenburgskaya-oblast

6. Дедеева С. А., Галушко М. В. Анализ развития сельского хозяйства Оренбургской области // Проблемы и перспективы экономики и управления. 2014. С. 61-69.

7. Журавлева М. А., Зубрев Н. И., Кокин С. М. Загрязнение придорожной зоны тяжелыми металлами // Мир транспорта. 2015. № 6. С. 174-181..

8. Зволинский В. П., Костыренко Е. И., Ракитина А. О. 2017. Загрязнение тяжелыми металлами почвы и растений в придорожных зонах города Астрахани // АПК России. 2017. Т. 24. № 4. С. 895-901.

9. Казанцев И. В., Матвеева Т. Б. Содержание тяжёлых металлов в почвенном покрове в условиях техногенеза // Самарский научный вестник. 2016. № 1(14). С. 34-37.

10. Косинова И. И., Фонова С. И. Исследование загрязнения тяжелыми металлами поверхностного слоя почвы придорожной территории автодороги M-4 в Воронежской области // Сергеевские чтения. Инженерно-геологические и геоэкологические проблемы городских агломераций. 2015. С. 418-422.

11. Кулакова Е. Н., Штепа А. А., Чернодубов А. И. Защитные лесные полосы вдоль автомобильных дорог // Вестник Казанского государственного аграрного университета. 2018. Т. 13. № 4. С. 46-50. https://doi.org/10.12737/ article_5c3de3817c03d1.22631961 
12. Леонидова Т. В., Сидоренкова Н. К., Блохина Н. А., Харитонов И. Д. Содержание тяжелых металлов в придорожной зоне автомобильных трасс // Международный журнал прикладных и фундаментальных исследований. 2019 . № 1. C. $146-149$.

13. Методика «Критерии оценки экологической обстановки территорий для выявления зон чрезвычайной экологической ситуации и зон экологического бедствия» (утв. Минприроды РФ 30.11.1992).

14. Мольков А. А., Рагимов А. О. Оценка экологического состояния почв придорожных территорий владимирской области в Судогодском районе // Современные тенденции в научном обеспечении агропромышленного комплекса. Иваново, 2019. С. 189-191.

15. Нестеров И. С., Петренко Д. Б., Васильев Н. В. Оценка загрязнения почв придорожных территорий московской области экотоксикантами. // Проблемы экологии Московской области: Сб. научных материалов. М.,. 2015. С. $200-205$.

16. Степовик Д. А. Состав и структура земель сельскохозяйственного назначения Оренбургской области // Известия Оренбургского государственного аграрного университета. 2010. № 1(25). С. 108-110.

17. Чекмарева О. В., Гарицкая М. Ю., Павлова Т. В. Экотоксикологическая характеристика качества почв, находящихся в зоне влияния Актюбинского завода ферросплавов // Вестник Оренбургского государственного университета. 2015. № 10(185). C. 448-450.

18. Esposito F. et al. Quercus ilex L. leaves as filters of air $\mathrm{Cd}, \mathrm{Cr}, \mathrm{Cu}, \mathrm{Ni}$ and $\mathrm{Pb} / /$ Chemosphere. 2019. Vol. 218. P. 340346. https://doi.org/10.1016/j.chemosphere.2018.11.133

19. Howard J. et al. Contributions of artifactual materials to the toxicity of anthropogenic soils and street dusts in a highly urbanized terrain // Environmental Pollution. 2019. Vol. 255. P. 113350. https://doi.org/10.1016/j.envpol.2019.113350

20. Khan Z. I. et al. Toxicological potential of cobalt in forage for ruminants grown in polluted soil: a health risk assessment from trace metal pollution for livestock // Environmental Science and Pollution Research. 2019. Vol. 26. № 15. P. $15381-15389$. https://doi.org/10.1007/s11356-019-04959-9

21. Krailertrattanachai N., Ketrot D., Wisawapipat W. The Distribution of Trace Metals in Roadside Agricultural Soils, Thailand // International journal of environmental research and public health. 2019. Vol. 16. № 5. P. 714. https://doi.org/10.3390/ ijerph16050714

22. Li T. et al. DNA Damage in Euonymus japonicus Leaf Cells Caused by Roadside Pollution in Beijing // International journal of environmental research and public health. 2016. Vol. 13. № 7. P. 742. https://doi.org/10.3390/ijerph13070742

23. Maeaba W., Prasad S., Chandra S. First Assessment of Metals Contamination in Road Dust and Roadside Soil of Suva City, Fiji // Archives of environmental contamination and toxicology. 2019. Vol. 77. № 2. P. 249-262. https://doi.org/10.1007/ s00244-019-00635-8

24. Mleiki A., Marigómez I., El Menif N. T. Green garden snail, Cantareus apertus, as biomonitor and sentinel for integrative metal pollution assessment in roadside soils // Environmental Science and Pollution Research. 2017. T. 24. № 31. P. $24644-$ 24656. https://doi.org/10.1007/s11356-017-0091-2

25. Thanneeru S., Li W., He J. Controllable Self-Assembly of Amphiphilic Tadpole-Shaped Polymer Single-Chain Nanoparticles Prepared through Intrachain Photo-cross-linking // Langmuir. 2019. Vol. 35. № 7. P. 2619-2629. https://doi.org/10.1021/ acs.langmuir.8b03095

26. Yan G. et al. The source apportionment, pollution characteristic and mobility of $\mathrm{Sb}$ in roadside soils affected by traffic and industrial activities // Journal of Hazardous Materials. 2020. Vol. $384 . \quad$ P. 121352. https://doi.org/10.1016/j.jhazmat.2019.121352

\section{REFERENCES}

1. Boguslavskaia, N. V. (2010). Ekologo-toksikologicheskaia otcenka soderzhaniia tiazhelykh metallov v agroland-shaftakh Belgorodskoi oblasti [Polevye opyty po soderzhaniiu kadmiia v pochve i ego nakopleniiu v raste-niiakh iarovoi pshenitcy]. Ekologicheskaia bezopasnost $v$ APK. Referativnyi zhurnal, (1), 108-108.

2. Vodyanitskii,Y. N., Vasil'ev, A. A., Chashchin, A. N., \& Savichev, A. T. (2010). The Influence of Technogenic and Natural Factors on the Content of Heavy Metals in Soils of the Middle CisUrals Region: The Town of Chusovoi and Its Suburbs Eurasian Soil Science, 43(9). 1011-1021.

3. Gailitis, D. I., \& Tuliankina, N. A. (2015). Biotestirovanie pochv s tceliu otcenki zagriazneniia pridorozhnoi polosy. In Problemy innovatcionnogo biosferno-sovmestimogo sotcialno-ekonomicheskogo razvitiia $\mathrm{v}$ stroitelnom, zhilishchnokommunalnom i dorozhnom kompleksakh (186-189).

4. Garitckaia, M. Iu., Chekmareva, O. V., Ishanova, O. S., \& Patokina, N. S. (2015). Khimicheskoe zagriaznenie pochv territorii prilegaiushchei k Sorochinsko-Nikolskomu mestorozhdeniiu. Vestnik Orenburgskogo gosudarstvennogo universiteta, (6(181)). 85-88.

5. Gosdoklad "O sostoianii i ob okhrane okruzhaiushchei sredyv Orenburgskoi oblasti v 2017 godu”. https://gosdokladecology.ru/2017/subjects/pfo/orenburgskaya-oblast/

6. Dedeeva, S. A., \& Galushko, M. V. (2014). Analiz razvitiia selskogo khoziaistva Orenburgskoi oblasti. In Problemy i perspektivy ekonomiki i upravleniia (61-69).

7. Zhuravleva, M. A., Zubrev, N. I., \& Kokin, S. M. (2015). Contamination of Roadside Areas With Heavy Metals. World of Transport and Transportation, (6). 174-181. (

8. Zvolinsky, V. P., Kostyrenko, E. I., \& Rakitina, A. O. 2017. Pollution of soil and plants by heavy metals in roadside zones of the city of Astrakhan. APK Rossii, 24(4). 895-901.

9. Kazantcev, I. V., \& Matveeva, T. B. (2016). Contents of Heavy metals in the Soil cover in the Conditions of Technogenesis. Samarskii nauchnyi vestnik, 1(14)). 34-37.

10. Kosinova, I. I., \& Fonova, S. I. (2015). Issledovanie zagriazneniia tiazhelymi metallami poverkhnostnogo sloia pochvy pridorozhnoi territorii avtodorogi M-4 v Voronezhskoi oblasti. In Sergeevskie chteniia. Inzhenerno-geologicheskie $i$ geoekologicheskie problemy gorodskikh aglomeratcii (418-422). 
11. Kulakova, E. N., Shtepa, A. A., \& Chernodubov, A. I. (2018). Protective Forest Strips Along automotive Roads. Vestnik Kazanskogo gosudarstvennogo agrarnogo universiteta, 13(4), 46-50. https://doi.org/10.12737/article_5c3de3817c03d1.22631961

12. Leonidova, T. V., Sidorenkova, N. K., Blokhina, N. A., \& Kharitonov, I. D. (2019). The Content of Heavy Metals in a roadside area of the highways. International Journal of Applied and Basic Research, (1). 146-149.

13. Metodika "Kriterii otcenki ekologicheskoi obstanovki territorii dlia vyiavleniia zon chrezvy-chainoi ekologicheskoi situatcii i zon ekologicheskogo bedstviia" (30.11.1992).

14. Molkov, A. A., \& Ragimov, A. O. (2019). Otcenka ekologicheskogo sostoianiia pochv pridorozhnykh territorii vladimirskoi oblasti v Sudogodskom raione. Sovremennye tendentcii v nauchnom obespechenii agropro-myshlennogo kompleksa. Ivanovo. 189-191.

15. Nesterov, I. S., Petrenko, D. B., \& Vasilev, N. V. (2015). Otcenka zagriazneniia pochv pridorozhnykh territorii moskovskoi oblasti ekotoksikantami. In Problemy ekologii Moskovskoi oblasti: sbornik nauchnykh mate-rialov, Moscow. 200-205.

16. Stepovik, D. A. (2010). Farm Lands Structure and Composition in the Orenburg Region. Izvestiia Orenburgskogo gosudarstvennogo agrarnogo universiteta, 1(25-1).

17. Chekmareva, O. V., Garitckaia, M. Iu., \& Pavlova, T. V. (2015). Ekotoksikologicheskaia kharakteristika kachestva pochv, nakhodiashchikhsia v zone vliianiia Aktiubinskogo zavoda ferrosplavov. Vestnik Orenburgskogo gosudarstvennogo universiteta, $(10(185))$.

18. Esposito, F., Memoli, V., Di Natale, G., Trifuoggi, M., \& Maisto, G. (2019). Quercus ilex L. leaves as filters of air Cd, $\mathrm{Cr}, \mathrm{Cu}, \mathrm{Ni}$ and $\mathrm{Pb}$. Chemosphere, 218, 340-346. https://doi.org/10.1016/j.chemosphere.2018.11.133

19. Howard, J., Weyhrauch, J., Loriaux, G., Schultz, B., \& Baskaran, M. (2019). Contributions of artifactual materials to the toxicity of anthropogenic soils and street dusts in a highly urbanized terrain. Environmental Pollution, 255, 113350. https://doi.org/10.1016/j.envpol.2019.113350

20. Khan, Z. I., Arshad, N., Ahmad, K., Nadeem, M., Ashfaq, A., Wajid, K., ... \& Sana, M. (2019). Toxicological potential of cobalt in forage for ruminants grown in polluted soil: a health risk assessment from trace metal pollution for livestock. Environmental Science and Pollution Research, 26(15), 15381-15389. https://doi.org/10.1007/s11356-019-04959-9

21. Krailertrattanachai, N., Ketrot, D., \& Wisawapipat, W. (2019). The Distribution of Trace Metals in Roadside Agricultural Soils, Thailand. International journal of environmental research and public health, 16(5), 714. https://doi.org/10.3390/ijerph16050714

22. Li, T., Zhang, M., Gu., K., Herman, U., Crittenden, J., \& Lu, Z. (2016). DNA Damage in Euonymus japonicus Leaf Cells Caused by Roadside Pollution in Beijing. International journal of environmental research and public health, $13(7), 742$. https://doi.org/10.3390/ijerph13070742

23. Maeaba, W., Prasad, S., \& Chandra, S. (2019). First Assessment of Metals Contamination in Road Dust and Roadside Soil of Suva City, Fiji. Archives of environmental contamination and toxicology, 77(2), 249-262. https://doi.org/10.1007/s00244019-00635-8

24. Mleiki, A., Marigómez, I., \& El Menif, N. T. (2017). Green garden snail, Cantareus apertus, as biomonitor and sentinel for integrative metal pollution assessment in roadside soils. Environmental Science and Pollution Research, 24(31), 2464424656. https://doi.org/10.1007/s11356-017-0091-2

25. Thanneeru, S., Li, W., \& He, J. (2019). Controllable Self-Assembly of Amphiphilic Tadpole-Shaped Polymer SingleChain Nanoparticles Prepared through Intrachain Photo-cross-linking. Langmuir, 35(7), $2619-2629$. https://doi.org/10.1021/acs.langmuir.8b03095

26. Yan, G., Mao, L., Jiang, B., Chen, X., Gao, Y., Chen, C., ... \& Chen, L. (2020). The source apportionment, pollution characteristic and mobility of $\mathrm{Sb}$ in roadside soils affected by traffic and industrial activities. Journal of Hazardous Materials, 384, 121352.https://doi.org/10.1016/j.jhazmat.2019.121352

Гарицкая М. Ю., Холодилина Т. Н., Баранова М. С. Экологическая характеристика качества почв придорожных территорий, используемых для выращивания сельскохозяйственных культур // Вестник Нижневартовского государственного университета. 2020. № 1. С. 119-126. https://doi.org/10.36906/2311-4444/20-1/18

Garitskaya, M. Y., Kholodilina, T. N., \& Baranova, M. S. (2020). Ecological characteristics of soil quality of roadside areas used for growing crops. Bulletin of Nizhnevartovsk State University, (1). 119-126. https://doi.org/10.36906/2311-4444/20-1/18 